Journal of Contemporary Research in Business, Economics and Finance

ISSN: 2641-0265

Vol. 3, No. 4, pp. 158-167.

2021

Publisher: Learning Gate

DOI: 10.33094/26410265.2021.34.158.167

(C) 2021 by the authors; licensee Learning Gate

\title{
Impact of Foreign Reserves and Economic Growth on Money Supply: Evidence from the WAMZ Countries
}

\author{
Foday Joof* \\ Risk Management Department, Central Bank of The Gambia, 1-2 Ecowas Avenue Banjul, The Gambia. \\ Email: fjoof@,cbg.gm (*Corresponding Author) \\ Alieu S. Ceesay \\ Economic Research Department, Central Bank of The Gambia, 1-2 Ecowas Avenue Banjul, The Gambia. \\ Email:aacessay@.cbg.gm
}

Received: 16 August 2021; Revised: 8 November 2021; Accepted: 6 December 202 1; Published: 23 December 2021

\begin{abstract}
This paper analyzes the impact of foreign currency reserve and economic growth on money supply using panel data from five West African Monetary Zone (WAMZ) member states from 2001-2019. The study employed the dynamic technique, fully modified ordinary least squares and dynamic ordinary least squares (FMOLS and DOLS), and the static method (fixed effect model) for the robustness check. The long run results showed that foreign currency reserves (FCR) have a positive impact on money supply, implying that a one percent increase in FCR augments money supply (M2) by 2.87\%, $0.44 \%$ and $0.08 \%$, respectively, in the long run. Similarly, economic growth is associated with an increase in money supply in both models. Furthermore, the Dumitrescu \& Hurlin (2012) estimation revealed a feedback association between foreign currency reserve and money supply. This means that foreign reserves and money supply are complementary. Conversely, a unidirectional causality moving from economic growth to M2 is observed, demonstrating that economic growth causes M2. This outcome is explained by the quantity theory of money (QTM) in which the velocity of money is a positive function of total money supply. As money circulates in the economy as a result of a surge in investments, this consequently increases money stock. Similarly, investment opportunities that are being exploited day-by-day explains the growing money stock (WAMI, 2018). Central banks should endeavor to monitor the expansionary influence of net foreign assets (NFA) on money supply growth in the WAMZ by establishing suitable methods to sterilize foreign exchange infusions into the economy.
\end{abstract}

Keywords: Foreign currency reserve, Money supply, Economic growth, WAMZ, FMOLS.

\section{Introduction}

This paper utilizes the FMOLS and DOLS, and static methods to empirically analyze the causal link and impact between foreign currency reserve and economic growth on money supply using panel data from five West African Monetary Zone (WAMZ) member states. Liberia was excluded from the study due to incomplete data.

The WAMZ policymakers have utilized fiscal and monetary policy mechanisms as a guide for countries' economic policies in reaction to the economic situation and public finance. Thus, one of the convergence criteria of the WAMZ is the accumulation of foreign reserves. The level of foreign reserves remains adequate on average in the WAMZ block, and some monetary authorities are actively accumulating foreign reserves for buffers, especially now that countries are more vulnerable to external and domestic shocks than before. The accumulation of foreign reserves is key for the WAMZ members to attain as one of the West African Monetary Institute (WAMI) convergence criterion. The WAMZ 
member states (The Gambia, Ghana, Guinea, Nigeria, and Sierra Leone, and Liberia) had gross external reserves levels that exceeded three months of import cover as of the end of June 2019 (WAMI, 2019).

Money supply grows moderately, although still strongly, supported by the foreign asset position of the banking system and sustained economic growth (GDP), which is the focus of monetary policy in all the member states. Money supply recorded double-digit growth in all member states: The Gambia (24.4\%), Ghana (22.1\%), Guinea (16.5\%), Nigeria (12.4\%) and Sierra Leone (15.9\%) at the end of June 2019 (WAMI, 2019). All the member states except Ghana adopted a monetary targeting framework, while the latter employed inflation targeting frameworks.

A monetary targeting framework targets reserve money as primary instrument to influence broad money (intermediary) and inflation (desired goal). Therefore, the monetary targeting framework suggests a positive relationship between the growth in reserve money, broad money and price changes. Thus, the reserve accumulation cannot be justified by investments (portfolio) or stabilization objectives. There is evidence that foreign reserve accumulation plays a crucial role in money growth, especially for countries with natural resources; (Li-Na \& Chuan-Zhe, 2008) in the case of China; Azar (2014) in Lebanon using the GARCH models; and Joof \& Tursoy (2020) in the case of the Gambia employing the ARDL model.

This paper contributes to the literature twofold. First, having observed the growth in money supply and foreign reserve coupled with the soaring inflation rates in The Gambia and Central Bank of The Gambia (CBG) mandate to ensure price stability, accumulation of foreign reserve, and economic growth, this called for a thorough investigation on the nexus among money growth, foreign reserve and economic growth, and to determine whether CBG's quest to boost foreign reserve and growth will increase money supply. According to the authors' knowledge, no study has investigated the long-run accumulation of foreign reserves and economic growth in the WAMZ. The few existing papers on the topic, such as Adi \& Riti (2017); Chinwuba, Oshoke, \& Thomas (2015); Joof \& Tursoy (2020); Onyeiwu (2012), were not conducted on WAMZ countries; the closest study to this paper is by Joof \& Tursoy (2020), who only tested the influence of foreign reserve on $\mathrm{M}$ 2, while ignoring economic growth. Furthermore, the abovementioned studies focus on time series estimations. However, this paper examines panel data from five countries using the fully modified OLS and dynamic OLS models, and the fixed effect model. The use of the dynamic panel is justifiable because FMOLS has superiority over the Engle and Granger (EG) techniques as it applies appropriate correction of inference problems posed by the EG method, and its long-run estimates are valid as the main purpose of FMOLS and DOLS estimators is to deal with endogeneity problems and autocorrelation.

One of the main limitations of the study is data constraints, which ranges from 2001-2019; this might not cover certain historical economic cycles of the central banks' monetary policies. The rest of the paper is organized the in following sections: section two contains the macroeconomic developments in the WAMZ member states, section three includes the theoretical and empirical review, and section four details the methodology. The findings, discussion, conclusion and recommendations are discussed in section five.

\section{Macroeconomic Developments in the WAMZ Member States \\ 2.1. Real GDP Growth}

Economic growth in the WAMZ are primarily premised on developments in agriculture and extractive sectors. However, low investments in extractive sectors and the lack of commercialization in agriculture limits the potentials of these sectors. This has led the member states' economies to accumulate more foreign reserves in order to tackle external vulnerabilities, such as high import bills, currency fluctuations and unfavorable commodity prices.

Economic growth in The Gambia had increased to $6.6 \%$ in 2018 compared to $4.6 \%$ in 2017; the growth was mainly attributed to the rebound in tourism and trade following the political impasse in 2016. Ghana's economy grew by $6.3 \%$ in 2018 , lower than the $8.1 \%$ in 2017 . The decline in growth was due to the moderation in the growth of the oil and gas sector. Growth slowed in Guinea to $8.7 \%$ 
compared to $13.4 \%$ in 2017 . The drop in growth was mainly due to underperforming agriculture and extractive sectors. Liberia's growth was estimated at $1.2 \%$ in 2018 compared to $2.5 \%$ recorded in 2017 , which is a result of slowdown in the secondary sector (industrial gold production and manufacturing), and the tertiary sector (services). Output grew by $1.9 \%$ in Nigeria, compared to the growth of $0.8 \%$ recorded in 2017. The growth was largely driven by the recovery in crude oil prices and the support of real sector activity through the various interventions by the Central Bank of Nigeria $(\mathrm{CBN})$. Growth in Sierra Leone declined, and real GDP grew by $3.5 \%$ in 2018 , relative to the $3.8 \%$ recorded in 2017 . The low performance was due to lower commodity prices globally, high operational costs of the main iron ore mining company as well as slower activities in the manufacturing sector.

\subsection{Monetary Sector}

All the member states in the WAMZ operate on a monetary targeting framework, with the exception of Ghana and Liberia, which employ inflation targeting and exchange rate targeting, respectively.

Member states' central bank mandates dictate the weight assigned to growth (output) and inflation. Some member states give more weight to growth, resulting in accommodative monetary policy measures to support output growth, whereas other primary mandates are weighted on low and stable prices, and warrant a tighter monetary policy stance to contain inflationary pressures. Broad money supply recorded double-digit growth in all the member states, attributable mainly to the growth in the net foreign assets (NFAs) of member states' central banks. By the end of December 2018, money supply had grown in The Gambia by $20.0 \%$, Ghana by $15.7 \%$, Guinea by $10.3 \%$, Liberia by $33.0 \%$, Nigeria by 12.\%, and Sierra Leone by 14.3\% (WAMI, 2018).

\section{Literature Review}

\subsection{The Nexus Between Foreign Reserves and Money Supply}

There is an abundance of empirical literature on the determinants of money supply (see Azar (2014); Joof \& Tursoy (2020); Li-Na \& Chuan-Zhe (2008). However, there are very few studies that have looked at the effects of international reserves and economic growth on money growth in the WAMZ countries. Efforts have been dedicated to this matter over the last decade as a result of its importance regarding the implementation of a single currency within the WAMZ blocks. Furthermore, it explores the correlation between money supply and output for all the 15 ECOWAS countries. The study showed that the percentage increases in broad money supply were higher than the corresponding GDP growth rates. However, an increase in net foreign assets (NFA) also often accounted for liquidity growth in Niger, Burkina Faso, Guinea Bissau, Nigeria, Sierra Leone, and Liberia.

Joof \& Tursoy (2020) investigated "the mystery behind foreign currency reserve sterilization in The Gambia” using the autoregressive distributed lag (ARDL), FMOLS and Granger causality tests on time series data from January 2002 to December 2019. They highlighted a positive association amid foreign reserves and M2. They also confirmed a bidirectional relationship between M2 and foreign currency reserve. Azar (2014) investigated "Foreign Reserve Accretion and Money Supply Creation" in the case of Lebanon using a generalized autoregressive conditional heteroskedasticity (GARCH) model from 1991-2014. The study found that foreign exchange reserve holds a positive correlation with M2 in the long run. Li-Na \& Chuan-Zhe (2008) examined the association between foreign reserve and M2 in China, and evidence showed that foreign reserve augments money supply due to the mutual long-run and short-run equilibriums. The causality analysis revealed bidirectional causation. Furthermore, Joof (2021) analyzed the co-movement between foreign currency reserves, economic growth and money supply in the WAMZ from 2001-2019. The study employed the fully modified ordinary least squares and dynamic ordinary least squares. The long-run results showed that foreign currency reserves and economic growth have positive impacts on money supply. Based on the literature, we can say that the liaison between foreign reserve and money supply is not widely studied by scholars. However, Joof \& Tursoy (2020) have explored the topic but with a focus on The Gambia. 


\subsection{The Nexus Between Economic Growth and Money Supply}

Various scholars have examined the relationship between money supply and economic growth in advanced, developing, and emerging economies.

WAMA (2009) carried out a basic statistical analysis of 15 ECOWAS nations from 2002 to 2008 to investigate the association between money supply and other macroeconomic indicators (GDP, exchange rate, inflation rate, etc.). The analysis showed that money supply has a positive influence on GDP depending on the structural circumstances, and that in all the 15 countries, percentage growth on money supply was greater than GDP. Njimanted, Akume, \& Mukete (2016) used the vector autoregression (VAR) technique to examine the effect of $\mathrm{M} 2$ on economic growth in the Central African Economic and Monetary Community (CEMAC). CEMAC was set up by a treaty signed in 1972 by six states, which include Cameroon, Chad, Equatorial Guinea, Gabon, The Central African Republic and the Republic of Congo. The analysis showed that M2 affects economic growth in diverse areas.

Prasert, Chokethaworn, Chaiboonsri, \& Khounkhalax (2015) employed the pooled mean group estimator (PMGE) to explore the relationship between money supply and economic growth of selected ASEAN economic cooperation countries (Cambodia, Indonesia, Laos, Malaysia, Philippines, Singapore, Thailand, and Vietnam) from 1995 to 2013 . Their results highlighted that money supply, which entails demand deposit and narrow money, had a positive association with economic growth. Furthermore, Bednarik (2010) used the vector autoregressive (VAR) model, Johansen cointegration technique, and the Granger causality test to investigate the association between real GDP and M3 from 2002 to 2009 in the Czech Republic, and the results indicated a robust and feedback association between M3 and GDP. Zapodeanu \& Cociuba (2010) employed the DVAR technique and cointegration analysis to test the association between money supply (M1, M2 and M3) and GDP in Romania from 1999 to 2010. Their outcome revealed a long-term cointegration between the indicators, and that the DVAR technique is the best fit for explaining the association among the indicators.

Havi \& Enu (2014) investigated the comparative prominence of monetary policy and fiscal policy on economic growth in Ghana from 1980 to 2012. They employed the ordinary least squares (OLS) technique, which showed that money supply and economic growth have a significant positive association. Precious \& Makhetha-Kosi (2014) utilized the error correction model and the Johansen cointegration test to study the influence of monetary policy on economic growth from 2000 to 2010 in South Africa. The results showed that money supply has a neutral relationship with economic growth. Using the error correction model on time series data spanning from 1980 to 2006 in Nigeria, Ogunmuyiwa \& Ekone (2010) propounded that expansionary and contractionary money supply has an insignificant influence on GDP. Onyeiwu (2012) evaluated the influence of monetary policy on GDP in Nigeria from 1981 to 2008 by means of OLS. The outcomes showed that money supply and GDP are positively related. Also in the case of Nigeria, Chinwuba et al. (2015) used the OLS model to estimate the link between GDP and M2 from 1981 to 2008. Their study suggested a positive co-movement between economic growth and money supply.

Overall, money supply and economic growth have been extensively studied, nevertheless, and the closest of these to our study is WAMA (2009), which employed a basic statistical correlation analysis of 15 ECOWAS nations. In this study, we try to fill the gap by using both the dynamic panel and static panel to check for robustness.

\section{Methodology}

\subsection{Data}

In scrutinizing the influence of foreign currency reserves (FCR) and economic growth (GDP) on money supply (M2) in the WAMZ (The Gambia,Guinea, Sierra Leone, Ghana, Nigeria), annual panel data of five members of the West African Monetary Zone is used. Data from 2001 to 2019 was sourced from the West African Monetary Institute database, and the choice of data was based on availability. The paper uses the framework of Joof \& Tursoy (2020). Money supply (M2) is the dependent variable, FCR and GDP are the explanatory variables, while inflation is the control variable. 
Where:

$$
\mathrm{LM} 2=\mathrm{f}(\mathrm{LFCR}, \mathrm{LGDP} \text { and INT })
$$

$\mathrm{LM} 2=\log$ of money supply

$\mathrm{LFR}=\log$ of foreign reserves

LGDP $=\log$ of economic growth

INT $=$ interest rate.

Table-1.

Variables' measurements.

\begin{tabular}{l|l|l|l}
\hline Indicators & Procedure & Unit & Source \\
\hline $\begin{array}{l}\text { Money Supply } \\
\text { (LM2) }\end{array}$ & $\begin{array}{l}\text { M1 coins and currency in circulation + } \\
\text { travelers' checks + demand deposits) } \\
\text { certificates of deposits + money market } \\
\text { funds + saving deposits + other time } \\
\text { deposits }\end{array}$ & West African Monetary \\
Institute WAMI (2019) & & \\
\hline $\begin{array}{l}\text { Foreign Currency } \\
\text { Reserve (LFCR) }\end{array}$ & Total foreign reserves held abroad & USD & $\begin{array}{l}\text { West African Monetary } \\
\text { Institute WAMI (2019) }\end{array}$ \\
\hline $\begin{array}{l}\text { Economic Growth } \\
\text { (LGDP) }\end{array}$ & GDP per Capita & USD & $\begin{array}{l}\text { World Bank (2019) } \\
\text { Institute WAMI (2019) }\end{array}$ \\
\hline \begin{tabular}{l} 
Interest (INT) \\
\hline
\end{tabular} & Monetary policy rate & $\%$ & Monetary \\
\hline
\end{tabular}

\subsection{Unit Root and Cointegration Tests}

Following the performance of the augmented Dickey-Fuller test (ADF) proposed by Maddala \& $\mathrm{Wu}$ (1999) and Breitung (2000), a unit root test to substantiate the existence of stationarity among the series, the cointegration method invented by Kao (1999) is applied, which is an extension of the Engle Granger causality in a panel context as a result of its first generation cointegration test residuals.

\subsection{Fully Modified $O L S$ and Dynamic OLS}

In this paper, dynamic long-run techniques, such as the fully modified OLS (FMOLS) and dynamic OLS (DOLS) invented by Pedroni (2001) and Mark \& Sul (2003), respectively, are utilized to analyze the impact of the independent variables on money supply. Pedroni (2004) argues that the FMOLS is superior to the Engle Granger (EG) techniques, as it applies suitable correction to solve the inference problems posed by the EG method. Furthermore, the FMOLS and DOLS estimators correct endogeneity problems and autocorrelation. FMOLS is a non-parametric test, which deals with serial correlation (Pedroni, 2001), and DOLS is a parametric approach with explicitly estimated lagged first differenced parameters (Saikkonen, 1991). Moreover, the FMOLS and DOLS should be stationary as a pre-requisite for all variables and the variables must be co-integrated as this assist in avoiding spurious analysis (Isiksal \& Joof, 2021). The choice of the variables was based on the theoretical framework of Joof \& Tursoy (2020), and the model is articulated as follows:

$$
\mathrm{LM} 2_{t}=\beta 0+\beta 1 \mathrm{LFCR}+\beta 2 \mathrm{LGDP}+\mathrm{INT}+\varepsilon i t ;
$$

Where:

$\mathrm{LM} 2=$ the log of money supply

$\mathrm{LFCR}=$ the $\log$ of foreign currency reserves

LGDP $=\log$ of economic growth

INT $=$ interest rate

$\varepsilon=$ the error term

$i=$ countries

$t=$ time period. 


\subsection{Fixed Effect and Random Effect Models}

To check the robustness of the FMOLS, we employed the fixed effects model (FEM) and random effects model (REM) approaches. The FEM is a technique with constants rather than with different intercepts centred on cross sections (nations or firms). Although intercepts can vary among countries, these intercepts do not vary (Gujrati, 2004). The OLS analysis estimates the general least squares fixed effect. Consequently, the resulting data are unbiased and consistent. In the fixed effects model, the variables are reflected by the intercepts, but in the random effects model (REM), the variances are accommodated by the error terms of the estimation. The Hausman investigation aids in choosing the appropriate technique between the FEM and REM. This testing is conducted with following hypotheses: Ho: If the p-value is $>0.05$, the REM is appropriate; H1: If the p-value is $<0.05$, the FEM is suitable.

\subsection{Dumitrescu and Hurlin (DH) Causality}

The Dumitrescu \& Hurlin (2012) causality analysis is applied to analyze the causal relationship between the regressors and the dependent variables. Once the cointegrating relationship among the series is established, it denotes a probable causal connection between the variables. Establishing these causal relationships can assist in validating the empirical findings (Isiksal \& Joof, 2021). and 4:

The Granger causality simple regression with $\mathrm{M}$ and $\mathrm{T}$ variables are represented in Equations 3

$$
\begin{aligned}
M_{t}= & a_{1}+\sum_{1}^{n} \beta_{1 i} N_{t-i}+\sum_{1}^{n} \beta_{2 i} M_{t-i}+u_{1 t} \\
& N_{t}=a_{2}+\sum_{1}^{n} \beta_{3 i} N_{t-i}+\sum_{1}^{n} \beta_{4 i} M_{t-i}+u_{2 t}(4)
\end{aligned}
$$

Where $\mathrm{n}$ denotes the number of lags; the $a_{1}, a_{2}, \beta_{1}, \beta_{2}, \beta_{3}, \beta_{4}$ parameters are to be estimated; $u_{1 t}$ and $u_{2 t}$ are the error terms. If the $\mathrm{M}$ variable does not cause the $\mathrm{N}$ variable, the combined parameters of $\mathrm{N}$ over the lagged $\mathrm{M}$ are nil.

Dumitrescu \& Hurlin (2012) introduced the Granger causality method for panel models by including cross-sectional units for $\mathrm{z}$ and $\mathrm{h}$ variables, which are stationary over $\mathrm{T}$ period and $\mathrm{N}$ individuals.

$$
z_{i, t}=v_{t}+\sum_{c=1}^{C} \mu^{(c)} z_{i, t-c}+\sum_{c=1}^{C} \beta^{(c)} h_{i, t-c}+e_{i t}
$$

\section{Presentation of Data}

\subsection{Description of Statistics}

The analysis in Table 2 suggested that money supply, economic growth, foreign reserves and inflation have an average annual growth rate of $7.9 \%, 6.8 \%, 6.8 \%$ and $12.0 \%$, respectively, in the selected WAMZ countries. The results also indicated that M2, GDP, FCR and INT have maximum rates of $11.5 \%, 8.1 \%, 11.1 \%$ and $39.1 \%$, with minimum rates of $4.9 \%, 5.7 \%, 3.1 \%$ and $0.4 \%$, respectively.

Table-2.

Descriptive Statistics.

\begin{tabular}{l|l|l|l|l}
\hline & LM2 & LGDP & LFCR & INT \\
\hline Mean & 7.855590 & 6.757536 & 6.829961 & 12.00760 \\
\hline Median & 7.438083 & 6.591928 & 6.271670 & 11.42090 \\
\hline Maximum & 11.52953 & 8.077973 & 11.07446 & 39.10000 \\
\hline Minimum & 4.935470 & 5.718883 & 3.141995 & 0.400000 \\
\hline Std. Dev. & 1.960032 & 0.615082 & 2.304634 & 6.169305 \\
\hline Skewness & 0.511555 & 0.471476 & 0.518998 & 1.459846 \\
\hline Kurtosis & 2.018902 & 2.233639 & 2.053598 & 6.819286 \\
\hline Sum & 659.8696 & 567.6330 & 573.7167 & 1008.638 \\
\hline
\end{tabular}




\subsection{Unit Root Test}

The augmented Dickey-Fuller (ADF) and Breitung tests showed that the series are stationary at $\mathrm{I}(1)$, thus the hypothesis that the series contained unit roots is discarded at the $5 \%$ significance level (Tables 3 and 4 ).

Table-3.

ADF Unit Root Test.

\begin{tabular}{|c|c|c|c|c|c|c|c|c|}
\hline \multirow{3}{*}{ 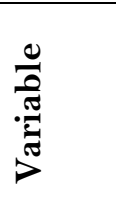 } & & Level & & & & $\begin{array}{c}\text { First } \\
\text { difference }\end{array}$ & & \\
\hline & Intercept & $\begin{array}{l}\text { Intercept } \\
\& \text { trend }\end{array}$ & & & Intercept & $\begin{array}{l}\text { Intercept } \\
\text { \& trend }\end{array}$ & & \\
\hline & $\mathrm{ADF}$ & P-value & ADF & P-value & $\mathrm{ADF}$ & P-value & ADF & P-value \\
\hline $\mathrm{LM} 2$ & 34.6734 & 0.9691 & 26.736 & 0.9986 & 172.55 & $0.0000^{* * * *}$ & 150.147 & $0.0000^{* * * *}$ \\
\hline LFCR & 36.2643 & 0.9522 & 61.588 & 0.1704 & 144.61 & 0.0000**** & 118.79 & 0.0000**** \\
\hline LGDP & 64.3307 & 0.1172 & 59.284 & 0.2272 & 152.30 & $0.0000^{* * * *}$ & 119.205 & $0.0000^{* * * *}$ \\
\hline INT & 57.5706 & 0.2767 & 67.289 & 0.0753 & 151.93 & 0.0000* $* * *$ & 109.033 & 0.0000* $* * *$ \\
\hline
\end{tabular}

Table-4.

Breitung Unit Root Test.

\begin{tabular}{c|c|c|c|c}
\hline Variables & \multicolumn{2}{|c|}{ Level \& intercept } & \multicolumn{2}{c}{ First Difference } \\
\hline & T-statistics & P-value & T-statistics & P-value \\
\hline LFCR & 0.02315 & 0.5092 & -2.11946 & $0.0170^{* * *}$ \\
\hline LGDP & 0.83129 & 0.7971 & -5.16628 & $0.0000^{* * *}$ \\
\hline LM2 & 2.64660 & 0.9959 & -4.71406 & $0.0000^{* * *}$ \\
\hline INT & -0.36692 & 0.3568 & -1.72604 & $0.0422^{* *}$ \\
\hline
\end{tabular}

\subsection{Kao Cointegration}

The Kao cointegration revealed the presence of long-run cointegration between the series, hence the p-value is $<0.05 \%$ significance, thereby rejecting the null inertia of no cointegration (see Table 5 ).

Table-5.

Kao Residual Test.

\begin{tabular}{l|c|c|c}
\hline Variable & T-statistic & P-value $^{* * *}$ & Cointegration \\
\hline LM2 $=$ f (LFCR, LGDP, INT) & -1.981581 & $0.0228^{* *}$ & Yes \\
\hline
\end{tabular}

Note: LM2 = money supply, LFCR = foreign currency reserve, and LGDP = gross domestic product. The bracket symbolizes the P-value while, ***, **, and * represent $1 \%, 5 \%$ and $10 \%$ significance levels, respectively.

\subsection{Hausman Test}

The Hausman test results in Table 6 suggest that the fixed effects model is preferable to the random effects model because the null hypothesis that the REM is better is discarded at 1\% significance level. As the Hausman test has shown the superiority of the fixed effects model over the random effects model, we deemed it unnecessary to tabulate the random effects.

Table-6.

Hausman Test.

\begin{tabular}{c|c|c|c|c}
\hline Variable & Fixed & Random & Var(Diff) & P-value \\
\hline LFCR & 0.067324 & 0.074553 & 0.000307 & 0.6800 \\
\hline LGDP & 0.120076 & 0.001002 & 0.000839 & $0.0000^{* * *}$ \\
\hline INT & -0.059567 & -0.010355 & 0.000161 & $0.0001^{* * *}$ \\
\hline Summary & & & & $0.0000^{* * *}$ \\
\hline
\end{tabular}




\subsection{FMOLS, DOLS and FE \\ 5.5.1. Findings}

Table 7 details the outcomes of the FMOLS, DOLS and FE models. The findings show that foreign currency reserves have a positive impact on money supply, implying that a one percent increase in FCR is associated with a rise in $\mathrm{M} 2$ by $0.13 \%, 0.31 \%$, and $0.07 \%$, respectively. This result conforms with the findings of Joof \& Tursoy (2020), who found a positive relationship between FCR and M2 in the case of The Gambia. Similarly, economic growth is associated with an increase in money supply in all three models. This suggests that a percentage increment in GDP will augment M2 by $0.76 \%, 0.81 \%$ and $0.12 \%$, respectively. Economic growth, which is triggered by a lower interest rate, usually causes total expenditures, interest-sensitive consumption goods and investment growth, and $\mathrm{M} 2$ tends to increase due to an increase in economic productivity. However, inflation has a negative insignificant relationship with money supply. The diagnostics (standard errors of the regression and long-run variance and Durbin-Watson) in the FMOLS, DOLS and FE models indicated that the models are specific and stable, and not suffering from heteroskedasticity or serial correlation. Furthermore, the $\mathrm{R}^{2}$ in the three models, which measures goodness-of-fit for linear regression models, stood at 0.99\%, and this suggests that $99 \%$ of the variance in $\mathrm{M} 2$ is explained by LFCR, LGDP and INT (explanatory variables) collectively. This showed that there is a strong association among the series.

Table-7.

FMOLS, DOLS and FE Techniques.

\begin{tabular}{c|c|c|c}
\hline Variable & FMOLS & DOLS & FE \\
\hline LM2 $(-1)$ & - & - & 0.790456 \\
\hline LFCR & 0.134859 & 0.306247 & 0.067324 \\
\hline LGDP & $(0.0088)^{* * *}$ & $(0.0021)^{* * *}$ & $(0.0098)^{* * *}$ \\
\hline INT & 0.762762 & 0.814866 & 0.120076 \\
\hline C & $(0.0000)^{* * *}$ & $(0.0000)^{* * *}$ & $(0.0264)^{* *}$ \\
\hline Durbin-Watson & $(0.5765)$ & -0.085870 & $-0.059567^{*} *$ \\
\hline R ${ }^{2}$ & - & $(0.4104)$ & $(0.0351)$ \\
\hline Adj. R ${ }^{2}$ & 0.994406 & - & 0.614209 \\
\hline S.E & 0.993389 & 0.999736 & 2.101177 \\
\hline Long run & 0.1590103 & 0.998723 & 0.997053 \\
\hline Note: LFC forign cur & 0.071218 & 0.000389 & \\
\hline
\end{tabular}

Note: LFCR = foreign currency reserve and LGDP = gross domestic product. The bracket symbolizes the Pvalue while, $* * * * *$, and $*$ represent $1 \%, 5 \%$ and $10 \%$ significance levels, respectively.

\subsection{Dumitrescu-Hurlin Panel Causality Test}

The analysis revealed that there is a two-way causation among foreign currency reserve and M2 (see Table 8). This means that foreign reserves and money supply are complementary. This also confirms the study by Joof \& Tursoy (2020), who found a feedback relationship in the case of The Gambia. Conversely, a unidirectional causality moving from economic growth to $\mathrm{M} 2$ is observed, demonstrating that economic growth causes M2. This outcome is explained by the QTM (quantity theory of money) in which the velocity of money is a positive function of total money supply. As money circulates in the economy as a result of a surge in investments, this causes an increase in money stock. Similarly, investment opportunities and potentials that are being exploited day-by-day stands as a ground for increasing money stock (Gatawa, Abdulgafar, \& Olarinde, 2017). A neutral causal association was found between interest rate and money supply. 
Table-8.

Dumitrescu-Hurlin Causality Test.

\begin{tabular}{l|l|l|l}
\hline Variables & W-Statistic & Zbar_Statistic & P-value \\
\hline LFCR $\leftrightarrow$ LM2 & 4.64381 & 3.89365 & 0.0001 * * $^{*}$ \\
\hline LGDP $\rightarrow$ LM & 2.57191 & 1.67033 & $0.0949^{*}$ \\
\hline INF $\neq$ LM2 & 2.27911 & 1.31183 & 0.1896 \\
\hline
\end{tabular}

\section{Conclusion}

This paper analyzed the influence of foreign currency reserve and economic growth on money supply using panel data of five WAMZs member states from 2001 to 2019 using the FMOLS and DOLS techniques, and the fixed effects method $(\mathrm{FE})$ as a robustness check. The results showed that foreign currency reserve has a positive impact on $\mathrm{M} 2$, implying that a one percent increase in FCR is associated with a rise in $\mathrm{M} 2$ by $0.13 \%, 0.31 \%$ and $0.07 \%$, respectively. This result is in conformity with the finding of Joof \& Tursoy (2020) who found a positive relationship between FCR and M2 in the case of The Gambia. Similarly, economic growth causes an increase in money supply in all three models. This suggests that a percentage increment in GDP will augment $\mathrm{M} 2$ by $0.76 \%, 0.81 \%$ and $0.12 \%$, respectively. Furthermore, the Dumitrescu-Hurlin causality estimation revealed a two-way causation between foreign currency reserve and M2. This means that foreign reserves and money supply are complementary. However, a unidirectional causation moving from economic growth to money supply was found, while a neutral causal association between inflation and $\mathrm{M} 2$ was found. It is not surprising that foreign currency reserve increases money supply in The Gambia because in the endeavor to boost foreign reserves, monetary authorities substitute domestic currency with foreign currency through intervention policies (purchasing foreign currency via the domestic market), and this increases the reserve money. It also supports the findings of WAMI (2018), that net foreign assets are the main driver of growth in money supply within the region.

\subsection{Recommendations}

Based on the abovementioned findings, we recommended the following:

(i) Central banks should monitor the expansionary influence of net foreign assets (NFA) on money supply growth in the WAMZ by establishing suitable methods to sterilize foreign exchange infusions into the economy.

ii) Growth in monetary base should be closely tied to the objective of stimulating growth. This will prevent the economy from overheating and inflation.

\section{References}

Adi, A. A., \& Riti, J. S. (2017). Determination of long and short run demand for money in the West African monetary zone (WAMZ) countries: A panel analysis. Econometric Research in Finance, 2(2), 79-97. Available at: https://doi.org/10.33119/erfin.2017.2.2.2.

Azar, S. A. (2014). Foreign reserve accretion and money supply creation: Lebanon's experience under an adjustable peg. International Journal of Financial Research, 5(3), 86-95. Available at: https://doi.org/10.5430/ijfr.v5n3p86.

Bednarik, R. (2010). Money supply and real GDP: The case of the Czech Republic. Retrieved from: http://papaers.ssrn. com/so13/papaers.cfm?abstract_id=1539390.

Breitung, J. M. (2000). The local power of some unit root tests for panel data. In: Baltagi BH (ed,), Nonstationary panels, panel cointegration, and dynamic panels (pp. 161-177). Amsterdam: Elsevier.

Chinwuba, O., Oshoke, A. S., \& Thomas, A. S. (2015). Monetary policy innovations and growth rate of output in Nigeria. IIARD International Journal of Economics and Business Management, 1(4), 1-15.

Dumitrescu, E.-I., \& Hurlin, C. (2012). Testing for Granger non-causality in heterogeneous panels. Economic Modelling, 29(4), 1450-1460. Available at: https://doi.org/10.1016/j.econmod.2012.02.014.

Gatawa, N., Abdulgafar, A., \& Olarinde, M. O. (2017). Impact of money supply and inflation on economic growth in Nigeria (1973-2013). IOSR Journal of Economics and Finance, 8(3), 26-37. Available at: https://doi.org/10.9790/59330803042637 .

Gujrati, D. N. (2004). Basic econometrics, United States military academy. West Point: Mc Graw Hill Publications. 
Havi, E. D. K., \& Enu, P. (2014). The effect of fiscal policy and monetary policy on Ghana's economic growth: Which policy is more potent. International Journal of Empirical Finance, 3(2), 61-75.

Isiksal, A. Z., \& Joof, F. (2021). Impact of bank performance on energy consumption: Evidence from selected commonwealth member states. International Journal of Global Energy Issues, 43(4), 402-418. Available at: https://doi.org/10.1504/ijgei.2021.117020.

Joof, F. (2021). The co-movement between foreign reserves, economic growth and money supply: Evidence from the WAMZ countries. Germany: University Library of Munich.

Joof, F., \& Tursoy, T. (2020). The mystery behind foreign reserve sterilization: Empirical evidence from the Gambia. Germany: University Library of Munich.

Kao, C. (1999). Spurious regression and residual-based tests for cointegration in panel data. Journal of Econometrics, 90(1), 1-44. Available at: https://doi.org/10.1016/s0304-4076(98)00023-2.

Li-Na, H., \& Chuan-Zhe, L. (2008). An empirical analysis of the relation of foreign exchange reserves and currency supply M2 in China. Paper presented at the 2008 International Conference on Management Science and Engineering 15th Annual Conference Proceedings.

Maddala, G. S., \& Wu, S. (1999). A comparative study of unit root tests with panel data and a new simple test. Oxford Bulletin of Economics and statistics, 61(S1), 631-652. Available at: https://doi.org/10.1111/1468-0084.61.s 1.13.

Mark, N. C., \& Sul, D. (2003). Cointegration vector estimation by panel DOLS and long-run money demand. Oxford Bulletin of Economics and Statistics, 65(5), 0305-9049.

Njimanted, F. G., Akume, D., \& Mukete, E. M. (2016). The impact of key monetary variables on the economic growth of the CEMAC Zone. Expert Journal of Economics, 4(2), 54-67.

Ogunmuyiwa, M., \& Ekone, A. F. (2010). Money supply-economic growth nexus in Nigeria. Journal of Social Sciences, 22(3), 199-204. Available at: https://doi.org/10.1080/09718923.2010.11892802.

Onyeiwu, C. (2012). Monetary policy and economic growth of Nigeria. Journal of Economics and Sustainable Development, 3(7), 62-71.

Pedroni, P. (2001). Fully modified OLS for heterogeneous cointegrated panels. In Nonstationary Panels, Panel Cointegration, and Dynamic Panels (pp. 93-130). Bingley, UK: Emerald Group Publishing Limited.

Pedroni, P. (2004). Panel cointegration: Asymptotic and finite sample properties of pooled time series tests with an application to the PPP hypothesis. Econometric Theory, 20(3), 597-625.

Prasert, C., Chokethaworn, K., Chaiboonsri, C., \& Khounkhalax, M. (2015). Money supply influencing on economic growthwide phenomena of AEC open region. Procedia Economics and Finance, 24, 108-115. Available at: https://doi.org/10.1016/s2212-5671(15)00626-7.

Precious, C., \& Makhetha-Kosi, P. (2014). Impact of monetary policy on economic growth: A case study of South Africa. Mediterranean Journal of Social Sciences, 5(15), 76-76.

Saikkonen, P. (1991). Asymptotically efficient estimation of cointegration regressions. Econometric Theory, 7(1), 1-21. Available at: https://doi.org/10.1017/s0266466600004217.

WAMA. (2009). Money supply growth and macroeconomic convergence in ECOWAS. West Africa Monetary Agency, Sierra Leone. Retrieved from: https://amao-wama.org/publications/wama-bulletin-december-2009/.

WAMI. (2018). Zonal macroeconomic development and convergence report. Ghana: West Africa Monetary Instituite.

WAMI. (2019). Zonal macroeconomic development and convergence report. Ghana: West Africa Monetary Instituite.

World Bank. (2019). World development indicators. Retrieved from: https://www.worldbank.org.data.

Zapodeanu, D., \& Cociuba, M. I. (2010). Linking money supply with the gross domestic product in Romania. Annales Universitatis Apulensis: Series Oeconomica, 1(12), 501. Available at: https://doi.org/10.29302/oeconomica.2010.12.1.50. 